\title{
COMPARATIVE ANALYSIS OF ADHERENCE TO THE MEDITERRANEAN DIET AMONG GIRLS AND ADOLESCENTS WHO PERFORM RHYTHMIC GYMNASTICS
}

\author{
ANÁLISE COMPARATIVA DA ADESÃO À DIETA MEDITERRÂNEA ENTRE CRIANÇAS EADOLESCENTES \\ DE GINÁSTICA RIITMICA
}

\begin{abstract}
ANÁLISIS COMPARATIVO DE ADHESIÓN A LA DIETA MEDITERRÁNEA ENTRE NIÑAS Y ADOLESCENTES
DE GIMNASIA RITTMICA
\end{abstract}

Mercedes Vernetta Santana' (Physical Education Professional)

Isabel Montosa Mirón²

(Physical Education Professional)

Leopoldo Ariza Vargas ${ }^{3}$

(Physical Education Professional)

Jesús López Bedoya ${ }^{4}$

(Physical Education Professional)

1. Universidade de Granada;

Faculdade de Ciências da Atividade

Física e o Esporte; Department

of Physical Education and Sports,

Spain.

2. Universidade de Córdoba,

Faculdade de Ciências da Educação,

Department of Art and Physical

Education. Spain.

Correspondence:

Isabel Montosa Mirón

isabelmontosa@gmail.com

\begin{abstract}
Introduction: Eating habits are one of the underlying aspects in rhythmic gymnastics as a sport with an aesthetic component. Objective: To evaluate adherence to the Mediterranean diet (MD) in girls and adolescents who perform rhythmic gymnastics, and the relationship of this adherence with Body Mass Index (BMI) and waist circumference. Methods: A prospective, descriptive comparative cross-sectional study with the participation of 221 gymnasts aged between 7 and 17 years. Adherence to the Mediterranean diet was analyzed using the KIDMED test. The waist circumference, height and weight of each gymnast were measured and the BMI calculated. Results: $41.63 \%, 52.94 \%$ and $5.43 \%$ of the total sample exhibited high, medium and low adherence, respectively, to the Mediterranean diet. The Mann-Whitney $U$ test indicated significant differences in the rate of adherence to the Mediterranean diet between the two age groups, $U=5007.0, p=.016, r=.162$. The adolescent gymnasts had greater adherence than the younger gymnasts. The total sample showed a positive correlation of the rate of adherence with weight (Rho $=.143, \mathrm{p}=.034)$, BMl (Rho $=.152, \mathrm{p}=.024)$ and waist circumference (Rho = $.180, p=.007)$. Conclusions: The eating habits of adolescent gymnasts with regard to the Mediterranean diet are healthier than those of the younger gymnasts. All participants had normal BMI values. The KIDMED values of the total sample were related to weight and BMI. The high percentages of younger gymnasts with mean adherence to the MD evidenced the need to approximate their eating habits with Mediterranean standards. Level of evidence ll; Comparative diagnostic study.
\end{abstract}

Keywords: Nutrition; Body composition; Diet, Mediterranean.

\section{RESUMO}

Introdução: Os hábitos alimentares são um dos aspectos fundamentais na ginástica rítmica como esporte de componente estético. Objetivo: Avaliar a adesão à dieta mediterrânea (DM) em crianças e adolescentes de ginástica rítmica e sua relação com o Índice de Massa Corporal (IMC) e o perímetro de cintura. Métodos: Estudo prospectivo, transversal, descritivo e comparativo onde participaram 221 ginastas entre 7 e 17 anos. Analisou-se a adesão à dieta mediterrânea através do teste KIDMED. Foram medidos o perímetro de cintura, assim como, a altura e o peso de cada ginasta, calculando o IMC. Resultados: 41,63\%, 52,94\% e 5,43\% da amostra total demonstraram a adesão à dieta mediterrânea alta, média e baixa respectivamente. $O$ teste $U$ de Mann-Whitney apontou diferenças significativas do índice de adesão à dieta mediterrânea entre os dois grupos de idade, $U=5007,0, p=, 016, r=, 162$. As ginastas adolescentes apresentaram maior adesão do que as crianças. A amostra total mostrou uma correlação positiva do indice de adesão com o peso (Rho = 143, $p=, 034), I M C(R h o=, 152, p=, 024)$, e perímetro de cintura ( $R h o=, 180$, $p=, 007)$. Conclusões: Os hábitos das ginastas adolescentes em relação à dieta mediterrânea são mais saudáveis do que das ginastas crianças. Todas apresentaram valores normais de IMC. Os valores de Kidmed da amostra total relacionaram-se ao o peso e ao IMC. As elevadas porcentagens de ginastas crianças com adesão média à DM evidenciam a necessidade de aproximar seus hábitos aos padrões mediterrâneos. Nível de evidência Il; Estudo de diagnóstico comparativo.

Descritores: Nutrição; Composição corporal; Dieta mediterrânea.

\section{RESUMEN}

Introducción: Los hábitos alimentarios son uno de los aspectos fundamentales en la gimnasia rítmica como deporte de componente estético. Objetivo: Evaluar la adhesión a la dieta mediterránea (DM) en niñas y adolescentes de gimnasia rítmica y su relación con el Índice de Masa Corporal (IMC) y el perímetro de cintura. Métodos: Estudio prospectivo, transversal, descriptivo y comparativo en donde participaron 221 gimnastas entre 7 y 17 años. Se analizó la adhesión a la dieta mediterránea a través del test KIDMED. Fueron medidos el perímetro de cintura, así como la altura y el peso de cada gimnasta, calculando el IMC. Resultados: 41,63\%, 52,94\% y 5,43\% de la muestra total demostraron la adhesión a la dieta mediterránea alta, mediana y baja respectivamente. El test U de Mann-Whitney apuntó 
diferencias significativas del índice de adhesión a la dieta mediterránea entre los dos grupos de edad, $U=5007,0$, $p=, 016, r=, 162$. Las gimnastas adolescentes presentaron mayor adhesión que las niñas. La muestra total mostró una correlación positiva del índice de adhesión con el peso ( $R h O=, 143, p=, 034), I M C$ (Rho =,152, $p=, 024$ ), y perímetro de cintura (Rho $=, 180, p=, 007$ ). Conclusiones: Los hábitos de las gimnastas adolescentes con relación a la dieta mediterránea son más saludables que los de las gimnastas niñas. Todas presentaron valores normales de IMC. Los valores de Kidmed de la muestra total se relacionaron al peso y al IMC. Los elevados porcentajes de gimnastas niñas con adhesión mediana a la DM evidencian la necesidad de aproximar sus hábitos a los estándares mediterráneos. Nivel de evidencia ll; Estudio de diagnóstico comparativo.

Descriptores: Nutrición; Composición corporal; Dieta mediterránea.

\section{INTRODUCTION}

An optimal diet with adequate energy intake is a factor that affects sports performance. Rhythmic gymnastics is an Olympic sport that requires performing the technical elements with excellent execution and synchronized with a song; furthermore, esthetic appeal is present. ${ }^{1,2}$ Therefore, the scores are affected by subjective parameters, such as a low body weight. Thus, these gymnasts often adhere to diets that are inadequate with regard to nutrient consumption. ${ }^{3}$

Several studies indicate that energy intake in female gymnasts is generally lower than the established recommendations. ${ }^{4-7}$ Frequently, insufficient caloric intake is associated with eating disorders, which is more frequent among female athletes than in the general population. ${ }^{8}$ Among athletes, these disorders are more prevalent in those who compete in sports in which weight and esthetics are important features, such as gymnastics. ${ }^{8}$ Thus, rhythmic gymnasts are considered to be at risk of presenting altered eating habits. ${ }^{9}$ Differently, other studies reported that rhythmic gymnasts present an energy intake that was appropriate or similar to that in the control groups. ${ }^{4,10-12}$

Studies involving child gymnasts are scarce and report an adequate energy intake for individuals in this age group.,11,12 However, children who practice sports with an esthetic component and compete prematurely display a greater concern about their weights than those who participate in sports that are not related to esthetics or simply do not participate in sports. ${ }^{13}$

Moreover, concerns related to the weight become more pronounced during puberty. ${ }^{3}$ In fact, the prevalence of unhealthy eating behaviors has been found to be higher among 14-year-old adolescents than among younger women. ${ }^{14}$

Currently, the Mediterranean diet (MD) is considered one of the healthiest dietary patterns and is beneficial against various diseases and, consequently, is related to a higher life expectancy. ${ }^{15}$

The MD is majorly composed of ingredients commonly found in the Mediterranean region, such as cereals, vegetables, fish, olive oil, fruits, dried fruits, vegetables, and greens. The degree of adherence to the MD may be quickly and effortlessly quantified through the application of the Mediterranean Diet Quality Index in children and adolescents (KIDMED). ${ }^{16}$ This index was compared with that in studies conducted in populations and communities in Spanish, which involved subjects of different age groups. ${ }^{17,18}$

The objective of this study was to investigate the degree of adherence to the MD of gymnasts classified as children and adolescents and to analyze the relationship with body mass index (BMI) and waist circumference, as well as to assess possible differences between these groups of athletes.

\section{MATERIAL AND METHOD}

A descriptive, cross-sectional, and comparative study was conducted in 221 gymnasts aged between 6 and 17 years distributed as follows:
56.11\% children between 7 and 12 years and $43.89 \%$ adolescents aged between 13 and 17 years. The study was conducted in different schools in Andalusia, Spain. Data collection was performed at the beginning of their training, after obtaining signed informed consent forms from parents according to the local current legislation (Decree 41/2002 of November 14). The study was approved by the ethics committee of the University of Granada ( $n^{\circ} .723 / \mathrm{CEIH/2018).}$

The following parameters were measured: waist circumference (SECA anthropometric tape, with the precision of $1 \mathrm{~mm}$ ), height (SECA220 stadiometer, with the precision of $1 \mathrm{~mm}$ ), and weight (TEFAL digital balance, with the accuracy of $0.05 \mathrm{~kg}$ ), and the body mass index (BMI) was calculated according to the Quetelet index $\left(\mathrm{Kg} / \mathrm{m}^{2}\right)$. As children and adolescents were evaluated, we employed the indicators proposed by Pan and Cole according to the BMI results, ${ }^{19}$ i.e., thinness grade III (below 16), thinness grade II (between 16.1 and 17), thinness grade I (between 17.1 and 18.5), normal (between 18.5 and 24.9), overweight (between 25 and 30), and obesity (above 30).

The quality of diet of participants was assessed according to the KIDMED index ${ }^{16}$ which is a questionnaire containing 16 items, in which indices may range from 0 to 12 . The questions with a negative answer regarding the MD were assigned -1 point and those with a positive answer were assigned +1 point. The sum of the values was classified into three levels according to their adherence to the MD as follows: scores above or equal to 8 indicate an optimal or good adherence, scores between 4 and 7 indicate average adherence, and scores below or equal to 3 indicated low adherence to the MD.

\section{Statistical analysis}

The normality and homoscedasticity of distributions were assessed using the Kolmogorov Smirnov and Levene tests, respectively. Non-parametric analysis was chosen when normal distribution was not observed in part of distributions of the adherence index, according to the different levels of the age variable. The comparison between independent samples was performed using the Mann-Whitney U Test. The effect size ( $r$ ) was calculated by applying the following formula:. Data are shown as mean ranges.

\section{RESULTS}

Table 1 shows anthropometric characteristics of gymnasts, categorized by two groups of ages. Results show that younger gymnasts present lower weight, height, and BMI than older gymnasts.

Table 2 presents data related to the adherence to the MD, according to the age groups.

Greater adherence to the MD was observed among adolescent gymnasts (49.48\%) than among child gymnasts (35.48\%).

A descriptive analysis was performed using data obtained from the KIDMED questionnaire items according to the age groups, i.e., $\leq 12$ and $\geq 13$ years, and results were compared with findings of the study EnKid España. (Table 3) 
Considering the value of the general factor obtained through the KIDMED, the Mann-Whitney $U$ test showed statistically significant differences in the MD adherence index between the age groups, $U=5007.0$, $p=0.016, r=0.162$. Gymnasts aged $\leq 12$ years presented lower adherence than those aged $\geq 13$ years. (Table 4 and Figure 1)

Table 1. Anthropometric characteristics of gymnasts according to their age.

\begin{tabular}{c|c|c|c}
\hline & $\mathbf{\leq 1 2}$ years & $\mathbf{2 1 3}$ years & Total \\
\hline Weight $(\mathrm{kg})$ & $29.23(7.38)$ & $48.15(5.11)$ & $38.54(11.42)$ \\
\hline Height $(\mathrm{m})$ & $1.33(0.13)$ & $1.58(0.4)$ & $1.44(0.16)$ \\
\hline BMI $\left(\mathrm{kg} \cdot \mathrm{m}^{-2}\right)$ & $16.32(1.73)$ & $19.38(1.79)$ & $17.66(2.32)$ \\
\hline Waist circumference $(\mathrm{cm})$ & $55.96(2.53)$ & $63.09(2.71)$ & $59.09(4.40)$ \\
\hline
\end{tabular}

The data are shown as mean values and standard deviation.

Table 2. Frequency (and percentage) of the adherence index and index of Pan \& Cole, according to the composition of the sample.

\begin{tabular}{c|c|c|c|c}
\hline & & \multicolumn{3}{|c}{ Age (years) } \\
\hline \multirow{4}{*}{$\begin{array}{c}\text { Adherence } \\
\text { Index }\end{array}$} & $\begin{array}{c}\mathbf{\leq 1 2} \text { years } \\
\mathbf{( n = 1 2 4 )}\end{array}$ & $\begin{array}{c}\mathbf{2 1 3} \text { years } \\
(\mathbf{n}=\mathbf{9 7})\end{array}$ & $\begin{array}{c}\text { Total } \\
(\mathbf{n}=\mathbf{2 2 1})\end{array}$ \\
\cline { 2 - 5 } & Poor $(\leq 3)$ & $10(8.06 \%)$ & $2(2.06 \%)$ & $12(5.43 \%)$ \\
\cline { 2 - 5 } & Gorage (4-7) & $70(56.46 \%)$ & $47(48.46 \%)$ & $117(52.94 \%)$ \\
\hline \multirow{4}{*}{$\begin{array}{c}\text { Pan \& Cole } \\
\text { Index }\end{array}$} & Thinness (Grade I) & $64(35.48 \%)$ & $48(49.48 \%)$ & $92(41.63 \%)$ \\
\cline { 2 - 5 } & Thinness (Grade II) & $21(16.9)$ & $3(3.1)$ & $69(31.2)$ \\
\cline { 2 - 5 } & Thinness (Grade III) & $20(16.1)$ & $17(17.5)$ & $28(12.7)$ \\
\cline { 2 - 5 } & Normal & $17(13.7)$ & $70(72.2)$ & $86(39.4)$ \\
\hline
\end{tabular}

Table 3. Percentage of positive answers in the KIDMED questionnaire for each item.

\begin{tabular}{|c|c|c|c|c|}
\hline KIDMED test & $\begin{array}{c}\leq 12 \text { years } \\
(\%)\end{array}$ & $\begin{array}{c}\geq 13 \text { years } \\
(\%)\end{array}$ & \begin{tabular}{|c|}
$\begin{array}{c}\text { Woman } \\
\text { KIDMED }^{27} \\
(2-14 \text { years }) \\
(\%)\end{array}$ \\
\end{tabular} & $p^{* *}$ \\
\hline $\begin{array}{l}\text { Consumes a fruit or a } \\
\text { natural juice daily. }\end{array}$ & 77.4 & 85.6 & 89.7 & .126 \\
\hline $\begin{array}{l}\text { Consumes a second } \\
\text { serving of fruit daily. }\end{array}$ & 33.1 & 43.3 & 62.8 & .119 \\
\hline $\begin{array}{l}\text { Consumes fresh (salads) or } \\
\text { cooked vegetables daily. }\end{array}$ & 59.7 & 78.4 & 68.9 & .003 \\
\hline $\begin{array}{c}\text { Consumes fresh or cooked } \\
\text { vegetables more than once daily. }\end{array}$ & 17.7 & 24.7 & 35.3 & .203 \\
\hline $\begin{array}{l}\text { Consume fish with regularity } \\
\text { (at least 2-3 times per week). }\end{array}$ & 73.4 & 69.1 & 82.5 & .481 \\
\hline $\begin{array}{l}\text { Goes once or more per week to a fast } \\
\text { food restaurant (hamburger type). }\end{array}$ & 21 & 11.3 & 1.9 & .057 \\
\hline $\begin{array}{l}\text { Likes vegetables and consumes } \\
\text { more than once per week. }\end{array}$ & 76.6 & 80.4 & 81.1 & .497 \\
\hline $\begin{array}{l}\text { Consumes pasta or rice almost } \\
\text { daily ( } 5 \text { or more days per week). }\end{array}$ & 61.3 & 63.9 & 37.8 & .689 \\
\hline $\begin{array}{l}\text { Consumes cereal or cereal product } \\
\text { (bread, etc.) for breakfast }\end{array}$ & 77.4 & 74.2 & 56.2 & .581 \\
\hline $\begin{array}{l}\text { Consumes dried fruits regularly } \\
\text { (at least 2-3 times per week). }\end{array}$ & 26.6 & 47.4 & 37.8 & .001 \\
\hline
\end{tabular}

Table 5 presents the correlation analysis yielded by the Spearman's Rho test for variables considered in the study, broken down according to the distinct age groups. There is no correlation between the adherence index to the MD and the rest of the paired variables, i.e., weight, height, $\mathrm{BMI}$, and waist circumference. However, a statistically significant positive correlation ( $p=0.000$ in all cases) was observed independently for all the pairs formed between the weight, height, BMI, and waist circumference for both children and adolescents.

The correlation study of the entire sample (Table 6) indicated a positive correlation of the adherence index with weight (Rho $=0.143$, $p=0.034)$, BMl (Rho $=0.152, p=0.024$ ), and waist circumference (Rho $=.180, p=0.007$ ). Furthermore, there was a statistically significant positive correlation ( $p=0.000$ in all cases) between all possible pairs formed between the weight, height, BMI, and waist circumference.

Table 4. Mid-range of the adherence index, according to the age groups.

\begin{tabular}{c|c|c|c}
\hline Age (years) & $\mathbf{N}$ & Mid-range & Sum of ranges \\
\hline$\leq 12$ & 124 & 102.88 & 12757.00 \\
\hline$\geq 13$ & 97 & 121.38 & 11774.00 \\
\hline
\end{tabular}

Table 5. Correlation analysis, according to the age groups. Spearman's rho test.

\begin{tabular}{|c|c|c|c|c|c|c|}
\hline & & Weight & Height & BMI & $\begin{array}{c}\text { Waist } \\
\text { circumference }\end{array}$ & $\begin{array}{c}\text { Adherence } \\
\text { index }\end{array}$ \\
\hline \multirow{3}{*}{ Weight } & $\begin{array}{c}\text { Spearman's } \\
\text { Rho }\end{array}$ & & $.919^{* *}$ & $.659^{* *}$ & $.429^{* *}$ & -.057 \\
\hline & Sig. (bilateral) & & .000 & .000 & .000 & .531 \\
\hline & $\mathrm{N}$ & & 124 & 124 & 124 & 124 \\
\hline \multirow{3}{*}{ Height } & $\begin{array}{c}\text { Spearman's } \\
\text { Rho }\end{array}$ & $.448^{* *}$ & & $.358^{* *}$ & $.418^{* *}$ & -.075 \\
\hline & Sig. (bilateral) & .000 & & .000 & .000 & .405 \\
\hline & $\mathrm{N}$ & 97 & & 124 & 124 & 124 \\
\hline \multirow{3}{*}{ BMI } & $\begin{array}{c}\text { Spearman's } \\
\text { Rho }\end{array}$ & $.917^{* *}$ & .129 & & $.295^{* *}$ & .008 \\
\hline & Sig. (bilateral) & .000 & .208 & & .001 & .933 \\
\hline & $\mathrm{N}$ & 97 & 97 & & 124 & 124 \\
\hline \multirow{3}{*}{$\begin{array}{c}\text { Waist } \\
\text { circumference }\end{array}$} & $\begin{array}{c}\text { Spearman's } \\
\text { Rho }\end{array}$ & $.350^{* *}$ & -.023 & $.372 * *$ & & -.017 \\
\hline & Sig. (bilateral) & .000 & .827 & .000 & & .851 \\
\hline & $\mathrm{N}$ & 97 & 97 & 97 & & 124 \\
\hline \multirow{3}{*}{$\begin{array}{l}\text { Adherence } \\
\text { Index }\end{array}$} & $\begin{array}{c}\text { Spearman's } \\
\text { Rho }\end{array}$ & .140 & .090 & .118 & & \\
\hline & Sig. (bilateral) & .172 & .379 & .249 & & \\
\hline & $\mathrm{N}$ & 97 & 97 & 97 & & \\
\hline \multicolumn{7}{|c|}{ **. The correlation is significant at the 0.01 level ( 2 tails). } \\
\hline \multicolumn{7}{|c|}{ Age Group: adolescent ( $\leq 12$ years) } \\
\hline \multicolumn{7}{|c|}{ Age Group: children ( $\geq 13$ years) } \\
\hline
\end{tabular}

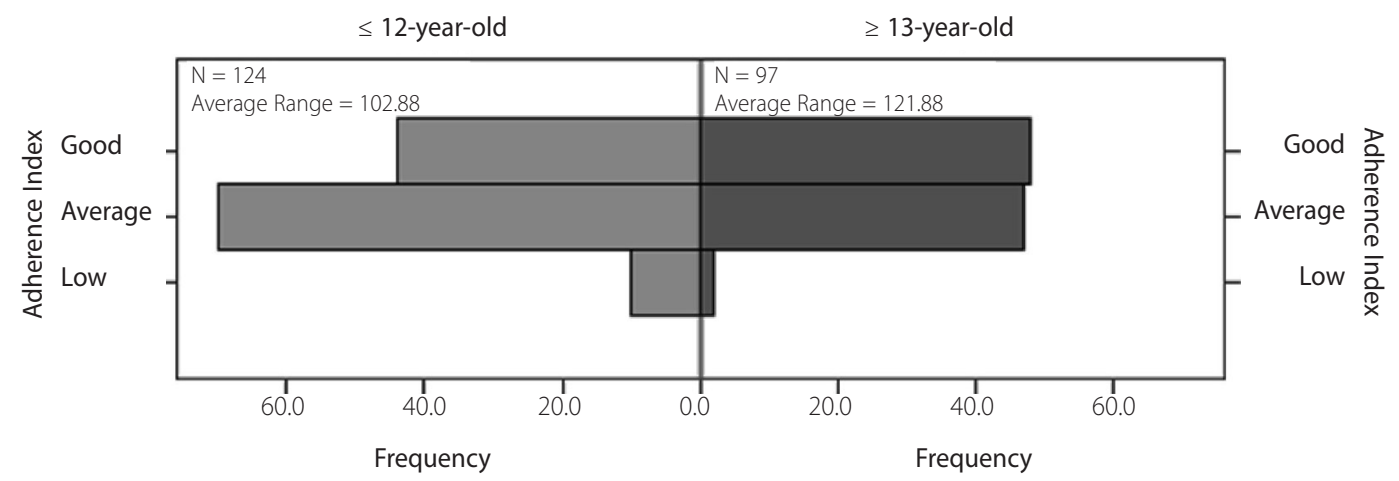

Figure 1. Average ranges of adherence to the Mediterranean diet, according to the age groups. 
Table 6. Correlation analysis of the complete sample. Spearman's rho statistics.

\begin{tabular}{|c|c|c|c|c|c|}
\hline & & Height & BMI & $\begin{array}{c}\text { Waist } \\
\text { circumference }\end{array}$ & $\begin{array}{c}\text { Adherence } \\
\text { index }\end{array}$ \\
\hline \multirow{3}{*}{ Weight } & Spearman's rho & $.925^{* *}$ & $.868^{* *}$ & $.791^{* *}$ & $.143^{*}$ \\
\hline & Sig. (bilateral) & .000 & .000 & .000 & .034 \\
\hline & $\mathrm{N}$ & 221 & 221 & 221 & 221 \\
\hline \multirow{3}{*}{ Height } & Spearman's rho & & $.668^{* *}$ & $.731^{* *}$ & .125 \\
\hline & Sig. (bilateral) & & .000 & .000 & .064 \\
\hline & $\mathrm{N}$ & & 221 & 221 & 221 \\
\hline \multirow{3}{*}{ BMl } & Spearman's rho & & & $699 * *$ & $.152^{*}$ \\
\hline & Sig. (bilateral) & & & .000 & .024 \\
\hline & $\mathrm{N}$ & & & 221 & 221 \\
\hline \multirow{3}{*}{$\begin{array}{c}\text { Waist } \\
\text { circumference }\end{array}$} & Spearman's rho & & & & $.180^{* *}$ \\
\hline & Sig. (bilateral) & & & & .007 \\
\hline & $\mathrm{N}$ & & & & 221 \\
\hline
\end{tabular}

**. The correlation is significant $(p<0.01)(2$ tails).

*. The correlation is significant $(p<0.05)(2$ tails).

\section{DISCUSSION}

Our main findings were that children and adolescent gymnasts present a normal weight and BMI and a low waist circumference, which were more pronounced in the children group. Moreover, data revealed the adherence to the MD to be average and good. Among the gymnasts sampled, there were correlations between the variables weight, BMI, and waist circumference and the MD adherence index (Table 6). Moreover, there were significant differences between the child and adolescent gymnasts regarding their degree of adherence, i.e., adolescents presented greater adherence than children (Table 4 and Figure 1).

The mean BMI value was $17.66 \mathrm{~kg} \cdot \mathrm{m}^{-2}$, and the majority of gymnasts presented either normal or slightly low weight, i.e., thinness grade I (Tables 1 and 2), according to the scale of Cole et al. ${ }^{19}$ Our finding was similar to that normally reported for rhythmic gymnasts ${ }^{20}$ but was lower than that reported by Ávila and Carvalho et al. ${ }^{21}\left(18.75 \mathrm{~kg} / \mathrm{m}^{2}\right)$ and higher than that reported by Soric et al. ${ }^{3}\left(16.9 \mathrm{~kg} / \mathrm{m}^{2}\right)$.

No significant differences were found in BMI between children and adolescents; however, there was a smaller percentage of child gymnasts with normal BMI and a higher percentage of gymnasts in this group presenting thinness compared to adolescents. (Table 2)

The mean waist circumference in the total sample was $59.09 \mathrm{~cm}$, which was lower than that reported by Ávila and Carvalho et al. ${ }^{21}$ and D'Alessandro et al. ${ }^{22}(67.05 \mathrm{~cm})$ and similar to that reported by Roman et al. ${ }^{23}(58.66 \mathrm{~cm})$.

In general, the lower BMI and waist circumference found in these gymnasts than the normal population is related to the importance these athletes confer to their weight and body image, as these are sports-related esthetics in which thinness and a good appearance are important factors to win and succeed. ${ }^{2}$

According to the total KIDMED score of the sample, percentages of good, average, and low adherence were $35.48 \%, 56.46 \%$, and $8.06 \%$, respectively, for children and $49.48 \%, 48.46 \%$, and $2.06 \%$, respectively, for adolescents. Adolescents showed greater adherence to the MD than children, with significant differences between the age groups $(U=5007.0$, $p=0.016, r=0.162)$. In this group, the percentage of good adherence surpassed the results for average and low adherence. However, in the group of $\leq 12$ years, good adherence to the MD was higher than average and low adherence. These results do not support the relationship between the age increase and decrease in adherence to the MD24 in the normal population, in which eating habits similar to the MD are lost when students advance in age and more independently make decisions about their nutrition. In our study, due to their greater maturity, adolescent gymnasts are more aware of taking care of their body weight and physical appearance to obtain better scores. ${ }^{2}$

The correlation analysis showed a positive relationship between adherence to the MD and weight ( $p=0.034), \mathrm{BMI}(p=0.024)$, and waist circumference ( $p=0.007$ ) for the total sample (Table 6). Similarly, a statistically significant positive correlation was found in all pairs formed from weight, height, BMl, and waist circumference ( $p=0.000$ in all cases).

However, no significant relationship was found between adherence to the MD and the remaining paired anthropometric variables, i.e., weight, height, BMI, and waist circumference, when assessed independently in each age group (Table 5).

Regarding the responses of gymnasts to each KIDMED item, significant differences were observed between both groups in 3 of the 16 items; thus, the percentage of child gymnasts who consumed vegetables more than once a day (item no 3) and dried fruits at least twice a week (item no10) was significantly smaller ( $p=.003$ and $p=.001$, respectively) than that of adolescent gymnasts. However, a significantly higher percentage of child gymnasts reported consuming industrialized products, biscuits, or cakes (item no14) compared to adolescent gymnasts $(p<.001)$. The answers to the remaining questions have similar percentages between both groups (Table 3).

Among the positive aspects found in the diet of these gymnasts, we found the use of olive oil by $94.4 \%$ among children and $88.7 \%$ among adolescents, and these results are similar to those reported by Mariscal-Arcas et al., ${ }^{25}$ in which more than $85 \%$ of the Grenadine families used olive oil for cooking. The results are higher than those reported by Serra, et al., ${ }^{16}$ which was $75.4 \%$; the presence of a dairy product at breakfast and the daily consumption of a portion of fruit. On the contrary, there were relatively high percentages for the following negative questions: going to fast food restaurants every week $11.3 \%$ of adolescents and $21 \%$ of children), not having breakfast $(11.3 \%$ of adolescent gymnasts), or consuming sweets or treats several times a day (20.2\% and $18.6 \%$, respectively).

Generally, there was a greater frequency of negative behaviors in child gymnasts. These data are in contrast to those reported by McVey et al., ${ }^{14}$ which indicated a higher prevalence of unhealthy eating behaviors among the 14-year-old adolescents than among children. Differences were also found when compared to the results of Spanish teenage school children in the south of Spain, ${ }^{25}$ in whom the less healthy nutritional habits at this stage could be due because parents do not influence their eating habits as much as those during infancy. These contradictory results between the normal population and gymnasts suggest that the practice of a sport related to esthetics, such as rhythmic gymnastics, has a positive effect on the consciousness of a balanced diet as well as an adequate control of body weight. Therefore, we could deduce that in adolescent gymnasts, the greater adherence to the MD may be because they are more aware of the importance of a good diet for their sports performance and of a perfect physical appearance before the judges in order to obtain better valuation in their exercises.

Data found are not comparable to those in similar athletes due to the lack of studies; therefore, comparison was made with a nonathlete population of the same age range. In our study, nearly 35.5\% of child gymnasts showed a high adherence to the MD, which is slightly lower than the Spanish reference population ${ }^{16}$ (47.9\%) (Table 3), than that found in 6-9-year-old children from Soria (between 52 and $55 \%),{ }^{26}$ and than that found in children under 10 years from the south of Spain (53.1\%). ${ }^{25}$ 
In contrast, adolescent gymnasts showed a slightly higher percentage (49.5\%) of good adherence to the MD when compared to the $37.1 \%$ of secondary female students in Leganés, ${ }^{18} 46.9 \%$ in 10-16 year-olds from Granada, ${ }^{25}$ and $42.9 \%$ in adolescents aged $13-16$ years from Pamplona. ${ }^{27}$

The data found in the adolescent gymnasts in our study do not corroborate with those in studies ${ }^{6,7}$ about inadequate intakes in athletes that warn about possible eating disorders that are frequently found in sports related to esthetics ${ }^{8,9}$ and depends on a subjective value of a smaller weight and stylized figure in the artistic compositions of the gymnasts.

Differently, greater adherence found in adolescents conform with that found in studies ${ }^{4,10}$ that observed energy intakes in this population to be adequate or similar to the normal population.

Comparing our data with studies performed in sports populations ${ }^{28,29}$ is difficult, considering the sports are not similar and do not cover the entire range of ages analyzed by us. However, in comparison with values found in adolescents who play indoor soccer ${ }^{20}$ (41.67\% of average adherence) and swimmers ${ }^{29}$ (36\% high adherence), the percentages of average and good adherence of adolescent gymnasts in our study were superior in all cases and similar to the only study with rhythmic gymnastics adolescents ${ }^{30}$, in which $52.2 \%$ of gymnasts presented a high adherence to the MD.

\section{CONCLUSIONS}

This study shows that the population of gymnasts, in general, presents healthy habits according to the MD as the majority showed good and average levels of adherence. Child gymnasts presented significantly lower adherence than adolescent gymnasts.

The KIDMED values of the total sample relate to the variables weight, height, BMI, and waist circumference found for gymnasts.

Longitudinal studies are needed to better understand the relationship between age, participation in competitions, and adherence to the MD among gymnasts of this sport. In future research, it would be advisable to analyze samples of different levels of competition so as to assess the potential relation among the physical conditions, percentage of fat, and their scores in competitions.

\section{ACKNOWLEDGEMENTS}

The authors would like to acknowledge all the coaches and gymnasts of rhythmic gymnastics involved in the study.

All authors declare no potential conflict of interest related to this article

AUTHORS' CONTRIBUTIONS: Each author made significant individual contributions to this manuscript. MV (0000-0003-1655-5070)*: intellectual concept of the article, creation of the project and experimental design phase, writing, argumentation, review and data analysis of the article; IM (0000-0001-7425-9902)*: participation in data collection (total), preparation of the Excel spreadsheet and inclusion of data in same, translation of the abstracts (English and Portuguese) and preparation of the format of the article, and submission of same; LAV (0000-0001-8914-2408)*: performance of the statistical analysis and presentation of the tables; JLB (0000-0003-0353-6647)*: reviewed and improved the article, introducing new paragraphs and performing a critical review of same. All authors approved the final version of the manuscript. *ORCID (Open Researcher and Contributor ID).

\section{REFERENCES}

1. Miletić $D$, Katić R, Maleš B. Some anthropological factors of performance in rhythmic gymnastics novices. Coll Antropol. 2004;28(2):727-37.

2. Vernetta M, Fernández E, López-Bedoya J, Gómez-Landero A, Oña A. Estudio relacional entre el perfil morfológico y estima corporal en la selección andaluza de gimnasia rítmica deportiva. Motricidad. Eur J Hum Mov. 2011;26:77-92.

3. Soric M, Misigoj-Durakovic M, Pedisic Z. Dietary intake and body composition of prepubescent female aesthetic athletes. Int J Sport Nutr Exerc Metab. 2008;18(3):343-54

4. Filaire E, Lac G. Nutritional status and body composition of juvenile elite female gymnasts. J Sports Med Phys Fitness. 2002;42(1):65-70.

5. Weimann E. Gender-related differences in elite gymnasts: the female athlete triad. J Appl Psychol. 2002;92(5):2146-52.

6. Cupisti A, D'Alessandro C, Castrogiovanni S, Barale A, Morelli E. Nutrition survey in elite rhythmic gymnasts. J Sports Med Phys Fitness. 2000;40(4):350-5.

7. Muñoz MT, de la Piedra C, Barrios V, Garrido G, Argente J. Changes in bone density and bone markers in rhythmic gymnasts and ballet dancers: implications for puberty and leptin levels. Eur J Endocrinol. 2004;151(4):491-6.

8. Sundgot-Borgen J, Torstveit MK. Prevalence of eating disorders in elite athletes is higher than in the general population. Clin J Sport Med. 2004;14(1): 25-32.

9. Nordin S, Harris G, Cumming J. Disturbed eating in young, competitive gymnasts: Differences between three gymnastics disciplines. Eur J Sports Science. 2003;3(5):1-14.

10. Courteix D, Lespessailles $E$, Jaffre C, Obert P, Benhamou CL. Bone mineral acquisition and somatic development in highly trained girl gymnasts. Acta Paediatr. 1999;88(8):803-8.

11. Nickols-Richardson SM, Modlesky CM, O'Connor PJ, Lewis RD. Premenarcheal gymnasts possess higher bone mineral density than controls. Med Sci Sports Exerc. 2000;32(1):63-9.

12. Zanker CL, Gannon L, Cooke CB, Gee KL, Oldroyd B, Truscott JG. Differences in bone density, body composition, physical activity, and diet between child gymnasts and untrained children 7-8 years of age. J Bone Miner Res. 2003; 18(6):1043-50

13. Davison KK Earnest MB, Birch LL. Participation in aesthetic sports and girls' weight concerns at ages 5 and 7 years. Int J Eat Disorder. 2002;31(3):312-7.

14. McVey G, Tweed S, Blackmore E. Dieting among preadolescent and young adolescent females. CMAJ. 2004;170(10):1559-61.

15. Martinez-González MA, de la Fuente-Arrillaga C, Nunez-Cordoba JM, Basterra-Gortari FJ, Beunza JJ, Vazquez Z, et al. Adherence to mediterranean diet and risk of developing diabetes: prospective cohort study. BMJ. 2008;336(7657):1348-51.

16. Serra-Majem L, Ribas L, Ngo J, Ortega RM, Garcia A, Pérez-Rodrigo C, et al. Food, youth and the
Mediterranean diet in Spain. Development of KIDMED, Mediterranean Diet Quality Index in children and adolescent. Public Health Nutr. 2004;7(7):931-5.

17. De la Montaña J, Castro L, Cobas N, Rodríguez M, Míguez M. Adherencia a la dieta mediterránea y su relación con el índice de masa corporal en universitarios de Galicia. Nutr Clin Diet Hosp. 2012;32(3):72-80.

18. Cabrero M, García A, Salinero JJ, Pérez B, Fernández JJ, Gracia R. Diet quality ad its relation to sex and BMl adolescents. Nutr Clín Diet Hosp. 2012;32(2):21-7.

19. Cole TJ, Flegal KM, Nicholls D, Jackson AA. Body mass index cut offs to define thinness in children and adolescents: international survey. BMJ. 2007; 335(7612):194.

20. Di Cagno A, Baldairi C, Battaglia C, Brasili P, Merni F, Piazza M et al. Leaping ability and body composition in rhythmic gymnasts for talent identification. J Sports Med Phys Fitness. 2008; 48(3):341-6.

21. Ávila-Carvalho L, Klentrou P, Palomero ML, Lebre E. Body composition profile of elite group rhythmic gymnasts. Sci Gymnastics J. 2012;4(1):21-32.

22. D'Alessandro C, Morelli E, Evangelisti I, Galetta F, Franzoni F, Lazzeri D, et al. Profiling the diet and body composition of subelite adolescent rhythmic gymnasts. Pediatr Exerc Sci. 2007;19(2):215-27.

23. Román ML, del Campo VL, Solana RS, Martín JM. Perfil y diferencias antropométricas y físicas de gimnastas de tecnificación de las modalidades de artística y rítmica. Retos: Nuevas Tendencias de Educación Física, Deporte y Recreación. 2012;21:58-62

24. Grao-Cruces A, Nuviala A, Fernández-Martínez A, Porcel-Gálvez AM, Moral-Garcia JE, Martínez-López EJ. Adherence to the mediterranean diet in rural and urban adolescents of southern Spain, life satisfaction, anthropometry, and physical and sedentary activities. Nutr Hosp. 2013;28(4):1129-35.

25. Mariscal-Arcas M, Rivas A, Velasco J, Ortega M, Caballero AM, Olea-Serrano F. Evaluation of the Mediterranean Diet Quality Index (KIDMED) in children and adolescents in southern Spain. Public Health Nutr. 2009;12(9):1408-12.

26. Pérez-Gallardo L, Bayona I, Mingo T, Rubiales C. Utilidad de los programas de educación nutricional para prevenir la obesidad infantil a través de un estudio piloto en Soria. Nutr Hosp. 2011;26(5):1161-7.

27. Ayechu Díaz A, Durá Travé T. Dieta mediterránea y adolescentes. Nutr Hosp. 2009;24(6):759-60.

28. Rubio-Arias JÁ, Ramos Campo DJ, Ruiloba Nuñes JM, Carrasco Poyatos M, Alcaraz Ramón PE, Jiménez Diáz FJ. Adhesión a la dieta mediterránea y rendimiento deportivo en un grupo de mujeres deportistas de élite de fútbol sala. Nutr Hosp. 2015;31(5):2276-82.

29. Philippou E, Middleton N, Pistos C, Andreou E, Petrou M. The impact of nutrition education on nutrition knowledge and adherence to the Mediterranean Diet in adolescent competitive swimmers. J Sci Med Sport. 2017; 20(4):328-32.

30. Vernetta M, Montosa I, López-Bedoya J. Dieta Mediterránea en jóvenes practicantes de gimnasia rítmica. Rev Chil Nutr. 2018;45(1):37-44. 